\title{
IIIIIIIIIIIIIIIII 症例報告 IIIIIIIIIIIIIIIII
}

\section{著明な顤部痛と可動域制限で発症した結晶誘発性環軸関節周囲焱の 1 例}

\author{
高橋 千晶，福田 修，小山 新弥，藤原 稔泰*, \\ 亀田 宏, 遠藤 俊郎**
}

\section{A Case of An Acute Crystal Periarthritis of The Atlanto-Axial Joint with Severe Neck Pain and Restricted Neck Movement}

by

Chiaki Takahashi, M.D., Osamu Fukuda, M.D., Shinya Koyama, M.D., Toshiyasu Fujiwara, M.D.*, Hiroshi Kameda, M.D., Shunro Endo, M.D.***

$$
\text { from }
$$

Department of Neurosurgery, Saito Memorial Hospital

Department of Orthopaedic Surgery, Saito Memorial Hospital*

Department of Neurosurgery, University of Toyama**

A 54-year-old female complained progressive severe neck pain and restricted neck movement after making lots of deep bows. Her axial CT showed calcification around the atlanto-axial joint. Under a diagnosis of acute crystal-induced periarthritis, we treated her by prednisolone (15mg per day for one week). Her severe neck pain improved quickly after two days. Calcification around the atlanto-axial joint on the CT vanished after one month. So we suspected it was acute inflammatory change induced by hydroxyapatite crystal.

Acute crystal periarthritis of this portion is very rare. It is important to treat by steroid quickly,when calcification around atlanto-axial joint with severe neck pain and restricted neck movement is diagnosed by CT scan.

Key words: atlanto-axial joint, crystal induced periarthritis, calcification, hydroxyapatite

Spinal Surgery $20(4): 253 \sim 256,2006$

\section{はじめに}

結晶誘発性関節周囲炎は，日常臨床において遭遇する 疾患であるが，環軸関節に急性発症することは極めて稀 である.

頚部の前屈動作を頻回に繰り返していたところ，耐え られないほど強い頚部痛と可動域制限で入院し，CTス キャンで環軸関節周囲に石灰沈着性の病変を認め，ステ ロイド投与が著効した結晶誘発性環軸関節周囲炎と考え られた稀な 1 例を経験したので文献的考察を加え報告す る.

\section{症 例}

患者：54歳の女性.

主訴：強い頚部痛と䅡部可動域制限

既往歴：特記すべきものはなし. 上皮小体機能異常，甲 状腺機能異常, 腎透析の既往はない

現病歷: 2005年 7 月，市町村合併により定数削減となっ た選挙に出馬した夫の支持者回りで, 連日数百回もお辞 儀を繰り返していた。 7 月16日早朝より左後䅡部痛が出 現し次第に増強したため, 同日夜, 当院救急外来を受診 した，後頚部中心に安静時痛, 全方向性の運動痛を訴え たが，神経学的異常所見はないため，非ステロイド性抗

(Received : June 16, 2006, Accepted : November 7, 2006)

齊藤記念病院 脳神経外科, 齊藤記念病院 整形外科*, 富山大学医学部 脳神経外科**（連絡先：高橋千晶, [現籍] T930-0194 富山大学 救急災害医学講座, 富山県富山市杉谷2630) Address reprint request to: Chiaki Takahashi, M.D., Department of Acute medicine, University of Toyama, 2630, Sugitani, Toyama city, Toyama, 930-0194 Japan 


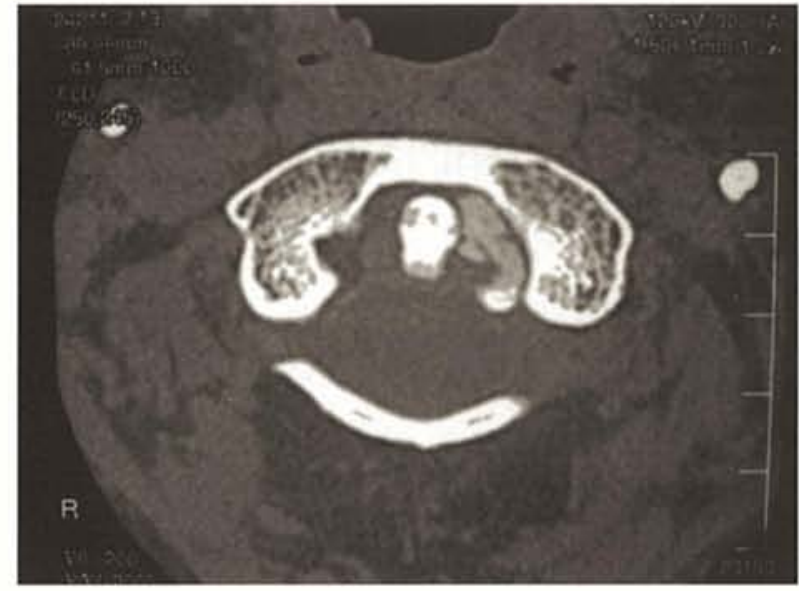

Fig. 1: Axial CT scan of upper cervical region demonstrating calcification in atlanto-axial joint before medication.

炎症凨，筋弛緩剤を処方され兴宅した．しかしその後， 頝部痛と可動域制限がさらに増強し，耐えがたい痛みと なったため, 7 月19日精査加療目的で入院となった.

検查所見 : 血液検查上, 白血球数は6300と正常值であっ た. 単純X線写真で菌突起後方に淡い石灰化像を認め, CT (Window Level 200, Width 2000) 画像では環軸 関節周囲の蒾突起左側に石灰沈着を認めた（Fig.1）. CT画像のA点とB点のCT值は500〜1000の範囲内にあっ た (Fig.2).

治療経過：結晶誘発性の環軸関節の急性関節炎を疑い, 頝部の安静, 頝椎装具の使用とともに, ブレドニソロン $15 \mathrm{mg}$ を連日 1 週間投与した. 投与開始後 2 日間で, 速 やかに症状は改善し， 7 月 27 日退院した. 退院後ステロ イドは漸減中止し，頝部痛と可動域制限は完全に消失し た. 1 ケ月後のCT画像でも同部位の石灰沈着像はほほ 消失した (Fig.3).

\section{考 察}

今回の症例の特徵は, 頚部の機械的な動きにより生じ た非常に強い急性炎症で，CT画像上， CT值500 1000 （血腫ではCT值40～60）の明瞭な石灰沈着所見を認め, ステロイド投与により急激に症状が消失し，それに伴い 石灰沈着も消失したことである.このような石灰沈着を ともなう急性炎症は, 肩関節・滕関節など大関節では日 常診療上見られるものの環刺関節では報告が極めて少な い.

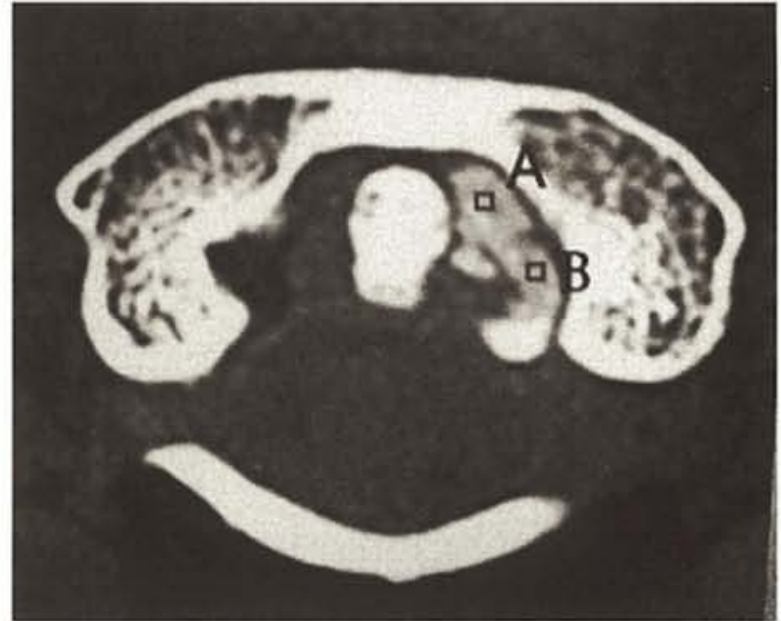

Fig. 2: We estimated nearly CT value on calcification from point $\mathrm{A}$ and $\mathrm{B}$.

沈着物質および病態として，石灰沈着をともなう急性 滑膜炎（関節炎，関節周囲炎，滑液包炎なと）には， （1）尿酸による痛風，（2）ピロリン酸カルシウム（以 下CPPD）による偽痛風，（3）塩基性リン酸カルシウ ム（ハイドロキシアパタイト）沈着による滑膜炎があ る. 尿酸による痛風に関しては単純X線写真では石灰沈 着を伴うことは稀であり，今回の症例に関しては，後二 者が想定される。

CPPDの結晶沈着は, 滕関節では半月板や滑膜内や関 節軟骨内の石灰沈着として認められ，㖊痛風発作が治ま っても自然に消失することはほとんどなく，経年的に石 灰沈着は增強しやすい [7]．結晶沈着の原因は，高龄 者の変形性関節症で見られることから，加粭に密接に関 連していると考えられるが，軟骨細胞の無機ピロリン酸 の代謝異常も指摘されている [8]. 環軸関節部の CPPD結晶による急性炎症の報告は少なく，松橋らの環 軸椎部の腾痛風 2 例の報告も, 後環軸椎靶带内に結晶沈 着が生じ，その腫瘤による神経圧迫が症状を起こしたの が主因で，腫㾇の切除により症状は消失している [9]. よって本症例は急性発症であり, 石灰沈着が速やかに改 善している点でCPPDの結晶沈着とは考えにくい.

ハイドロキシアパタイトの結晶沈着は, 局峰下滑液包 や肩腱板など肩関節では散見されるが, 肩関節以外にも 股関節，时関節，手関節，手指などに幅広く生じると報 告されている [10]. 動物実験で，ハイドロキシアバ夕 イトの結晶沈着が急性炎症反応を起こすことが証明され ている [1]. 結晶の沈着・吸収のメカニズムについて 


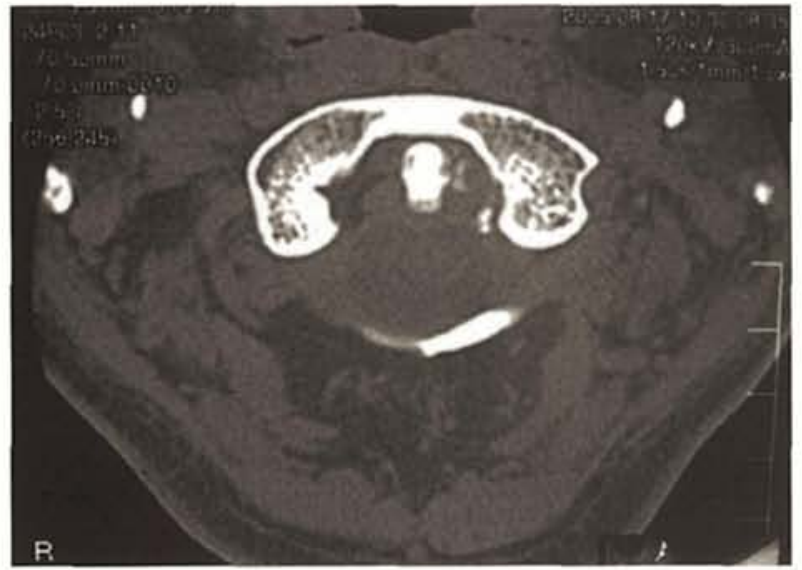

Fig. 3: Axial CT scan of upper cervical region demonstrating improvement ofcalcification in atlantoaxial joint after 1 month from previous CTscan.

は, 細胞内のオステオボンチンがその制御に関係してい るという報告もあるが [11], 急性炎症が起きるか否か を決定する要因は不明で, 結晶の性状とは関連していな いようである [4]. 環軸関節部の結晶沈着が慢性に経 過し, 次第に增大して頝部の可動域制限や神経圧迫症状 を呈した症例の報告があり [2，5，6，12]，また， 環椎横䩒带の石灰化は高龄者では散見され, 頚椎CTで 700例中40例に石灰化を認めたという報告もある [14]. 急性期の治療は, 安静, 冷却, 可能であれば液状沈着結 晶の穿刺吸引除去, 可能であればステロイドを局所注入 する. 局所注入が不可能ならステロイドを全身投与し， 改善が無ければ外科的除去が望ましいと報告されている $[3,13]$. 我々の症例では局所注人が困難なため, ステ ロイドの全身投与を行い, 著効したものである. 本症例 では組織㟝断がなされておらず, 明確な病名は不明であ るが, 解剖学的に鞋带の走行とは石灰沈着が一致してお らず, 環椎横靶带の石灰化とは異なるものであり，郜 床経過やステロイドに対する反応性から，ハイドロキシ アパタイト結晶による結晶誘発性の環軸関節周囲炎が最 も疑わしいと考えた. 強い頝部痛と可動域制限を呈する 症例に対しては, 早期に䅡椎のCTを施行し, 環軸関節 部に炎症性の石灰沈着を認めた場合早期にステロイドの 投与を考虑する必要がある.

\section{結 語}

頝部の頻回な前屈動作が誘引となり生じた, ハイドロ キシアバタイト結晶沈着をともなう結晶誘発性環軸関節 周囲炎と考えられた 1 例を報告した. 早期診断とステロ イド投与が望ましいと考えた.

\section{文 献}

1. Dieppe PA, Crocker P, Huskisson EC, et al: Apatite deposition disease. A new arthropathy. Lancet 1: 266-269, 1976

2. Dirheimer Y, Bensimon C, Wackenheim C, et al: Symdesmo-odontoid joint and calcium pyrophosphate dihydrate deposition disease(CPPD). Neuroradiol 25: 319-321, 1983

3. Garcia GM, McCord GC, Kumar R: Hydroxyapatite crystal deposition disease. Semin Musculoskelet Radiol 7: 187-193, 2003

4. 浜田純一郎, 大野 弥, 玉井和哉: 肩石灰性腱炎に おける急性, 慢性炎症経過は結晶の性状差で起こ るか. 肩関節 28: 301-304, 2004

5. Heldo G, Samuel M. Chou: Myeloradiculopathy secondary to pseudogout in the cervical ligamentum flavum. Case report. Neurosurg 25: 298-302, 1989

6. Kakitsubata Y, Boutin RD, Resnick D, et al: Calcium pyrophosphate dihydrate crystal deposition in and around the atlantoaxial joint: association with type 2 odontoid fracture in nine patients. Radiology 216: 213-219, 2000

7. 加藤 隆, 岩田岳志, 加藤哲司 5 : CPPD結晶沈 着症のX線診断. 滕 18: 146-149, 1993

8. 益田郁子: 結晶沈着性関節症. CONNECTIVE TISSUE 31: 88, 1999

9. 松橋智弥, 種市 洋, 須田浩太: 環軸椎に発生した CPPD結晶沈着症 (伪痛風) の 2 例. 北海道整形災 害外科学会雑誌 $45: 24,2004$

10. 末松典明, 菅原 修, 片山 耕: 有痛性の石灰沈着 性関節周囲炎（肩を除く）20例の検討. 中部日本 整形外科学会雑誌 37: 1163-1169, 1994

11. 菅本一臣, 乾 浩明, 原田 拓ら: 石灰性腱炎の石 灰沈着の分子制御機構. 厉関節 25: 193-196, 2001

12. Sutro J Charles: Calcification of the anterior atlanto-axial ligament as cause for painful 
swallowing and for painful neck. J Bone \& Joint Surg Dec 46A: 1753, 1964

13. 上田礼子, 藤本輝世子, 菅原幸子ら: 疼痛性石灰沈 着症. CONNECTIVE TISSUE 1: 38, 1969

14. Zapletal J, Hekster RE, Hermans J, et al: Association of transverse ligament calcification with anterior atlanto-odontoid osteoarthritis: CT findings. Neuroradiol 37: 667-669, 1995

\section{Reviewer's comment：秋野 実（札幌麻生脳神経外科病院）}

強い䝺部痛頚椎可動域制限を呈する症例では，常に頭蓋頝椎移行部の病変を考えなければならない. 特に小 児の場合，環椎軸椎亜脱臼を念頭に入れなければならないが，本症例のように，選挙運動での日本的慣行のお 辞儀がこのような強烈な頚部痛を引き起こしたことは興味樑い症例である．保存療法のため結晶誘発性の関節 周囲炎の病理学的証明はなされていないが，画像所見で石灰沈着とその吸収過程が明確にしめされており，本 論分は十分な価值を有するものと考えられる.

\section{Reviewer's comment：寶子丸＼cjkstart稔（大津市民病院＼cjkstart脳神経外科）}

本報告では環軸関節周囲に一過性の石灰沈着性の病変を認めた非常に稀な症例が記述してあります．CTで は病変は左側で，歯突起は若干右側へ変移しており軽度のmass effectが認められます。痛みは左側に限局して いることより，病変による局所的な刺激により痛みが発生していることが示唆されます。保存的加療により症 状が改善するとともに1ヶ月後のC Tでは蒾突起の変移は解消され正中に戻っています．手術がなされていな いために実際に何が沈着したかは不明でありますが，著者らは臨床像から塩基性りン酸カルシウムの沈着では なかったかと推論しておられます。おそらくは肩関節で時々遭遇する石灰沈着性腱板炎calcific tendinitisが環 軸関節に発生したものであると思われます。将来このような症例に遭遇した際に治療方針を決定する上で本報 告は有用であると考えられます。 